\title{
On the scope of protection of renowned trade marks*
}

\author{
Gustavo Ghidini \\ Professor, University of Milan and University LUISS Guido Carli, Rome, Italy \\ Giovanni Cavani \\ Professor, University of Modena, Italy
}

The aim of this paper is to define the scope of protection afforded to 'marks with reputation' under EU Directives and Regulations. The authors argue that the protection granted to said marks also in relation to 'not similar' goods requires that, having regard to all the circumstances of the specific case, the consumer could be induced to reasonably suppose that the trade mark owner is somehow (industrially or commercially) connected with the circulation of products bearing an identical or confusingly similar sign. If this possibility cannot be assessed, it should be denied that the use of that sign either brings an unfair advantage to the third party user, or is detrimental to the distinctive character or the repute of the renowned trade mark. In sum, the thesis here submitted states that the protection afforded to renowned trade marks, even 'extra moenia' (ie beyond the risk of confusion in a strict sense between the products), anyway presupposes that a misleading message is conveyed to the consumer, inducing her/him to 'transfer' the reputation of the latter's products to those of the third party user's products, with the effect of altering the consumer's purchasing choices.

Keywords: marks with reputation (renowned trade marks), identical or similar products, consumers' perception, business connection, distinctive function, 'investment function', Regulation (EU) No 2424/2015, Directive 2436/2015/EU, Regulation (EU) No 1001/2017

\section{INTRODUCTION}

As with IPRs in general, defining the scope of the protection of trade marks directly impacts on the extension of competitors' freedom: in particular, here, of freedom of commercial communication. This is particularly evident as concerns 'marks with reputation', which have enjoyed an enlarged protection under EU Directives and Regulations since the late 1980s, and the ensuing national legislation. Hence the interest in a tentative in-depth reconstruction of the scope of legal protection of said signs - also in relation to business sectors that are 'not similar' to those of registration. For a better understanding of our arguments, it is useful to preliminarily submit a brief reconstruction of the salient features of the European framework in which the rules on such marks are situated, that is, the 'reform' (and ensuing national laws) that since the late 1980s have modified the original historical perspective of trade mark law ('the classic regime'), shaped by national legislations under the aegis of the Paris Universal

* This article was based on section IV, Chapter 4 of Gustavo Ghidini, Rethinking Intellectual Property: Balancing Conflicts of Interest in the Constitutional Paradigm (Edward Elgar, Cheltenham 2018), which was co-written with Professor Giovanni Cavani of Modena University. 
Convention (articles 6-9). By the 'reform' we obviously refer to the regime from the original trade marks Directive and Community Trade Mark Regulation ${ }^{1}$ up to the the recent 'Trade Mark Reform Package' ${ }^{2}$ - bearing in mind that the innovations carried by these more recent acts do not basically alter the systemic tenets and jurispolitical inspiration of the basic reform dating back to the late 1980s and early 1990s.

\section{THE TWO SOULS OF THE 'REFORMED’ EU REGIME}

The 'reform' essentially aims at reconciling the core of the classic regime, which is the legal protection of the trade mark's function to distinguish the firms' market identity, with the contemporary trend to evaluate trade marks as goods per se. The first objective is the safeguarding of market transparency against confusion (ie to avoid a misleading 'association' of identities) as to the origin of the goods. This objective is realized by enabling the owner of a trade mark to prohibit unauthorized third parties from 'infringing' this mark, that is, using - in the sector of registration, or similar sectors - signs that are identical or similar to the owner's, so misleading the consumer in relation to the origin of the product. ${ }^{3}$ That distinctive function is a fundamental, nay indispensable, bulwark of market transparency, in a 'free initiative' and competitive economic framework.

The second objective is the aim of protecting the trade mark beyond the mere information as concerns the products' origin, making it possible for the owner to exploit the mark's commercial attraction as an autonomous ( per se) value/good, even irrespective of the vicissitudes of the undertaking whose products they originally distinguished. ${ }^{4}$

This second objective had basically come to the fore, along with its main corollaries, in the case law several years preceding the reform. It was a by-product of the emergence of new 'modes of production' characterized by the standardization of products, the specialization of manufacture, the decentralization (domestically and 'off shore') of production and trade, as well as by the related phenomena of the territorial expansion of markets (also facilitated by the Internet), the broadening, through licensing and merchandising practices, of the range of goods offered on the market, and by the many-faceted forms of industrial and commercial cooperation among firms. It was also characterized, with particular impetus, by the 'universality' and speed of electronic communications.

On the legal plane, that trend translated first and foremost into the requests advanced by business and professional circles linked to the 'brand industries' (typically, albeit not exclusively, producers of consumer goods) to be enabled to freely transfer/assign/ license the sign, irrespective of its original link with a certain firm - just as any other good employed in the undertaking's activity. Concerning, and coherently with, the abovementioned request, the owners of renowned brands also advanced the request to enlarge the protection of their trade mark and (hence) their intrinsic 'attractive' selling power, even beyond the original sector of registration and traditional use, with the aim of 'maximizing' the revenues obtainable from their brands.

1. Directive 89/104/EU and Regulation (EC) No 40/94 (Trade Marks Directive).

2. Directive 2436/2015/EU and Regulation (EC) No 207/2009 as modified by Regulation (EU) No 2424/2015 and now codified as Regulation (EU) No 2017/1001 (EUTM Regulation). 3. That function is the sole legal one expressly mentioned by the aforementioned EU legislation (Recital 16 of the 2015 Directive and Recital 8 of the Regulation). The same legislation, moreover, expressly extols its defensive role against the risk of confusion: see the aforementioned Recitals (more in $\S 3$ ).

4. EUTM Regulation, Recital (11). 
And, in fact, as is known, one of the more salient features of the reform is the extension of the exclusive protection of renowned trade marks, ${ }^{5}$ to sectors 'not similar' to that of registration - thus also allowing owners to grant and enforce licences for branding products even outside (precisely, 'inside' and 'outside') - the scope of their productive know-how and experience.

\section{PRELIMINARY DEFINITION OF THE NOTION OF 'RENOWNED TRADE $M A R K^{\prime}$}

The normative text providing for such an 'extramural' extension has remained substantially the same. Thus, in particular, the legal conditions of the extension were, and have remained: (a) the absence of 'due cause' of the unauthorized use by third parties of a trade mark identical or similar to a prior registered 'mark with reputation'; and (b) the verification that 'the use of that sign takes unfair advantage of, or is detrimental to, the distinctive character or the repute of the EU trade mark' (article 9(2)(c) of EUTM Regulation and article 10(2)(c) of the Trade Marks Directive). ${ }^{7}$

A tentative reconstruction of this regime ${ }^{8}$ may opportunely commence from two preliminary clarifications affecting the scope of the protection of these marks.

First of all, the notion of 'reputation' does not necessarily correspond to high renown (haute renommée) or fame, as was thought to be the case before the reform. Certainly, the more famous the trade mark, the more distinctive and suggestive its appeal will be. However, the normative notion includes - as confirmed by the $\mathrm{CJEU}^{9}$ - not only famous signs but any trade mark known to 'a significant portion of the public'. It is thus not a threshold defined in terms of quantity (such as market share or the like), which in the ultimate analysis only excludes trade marks of mere local renown. But as even these can become known at the national level simply through a strong injection of advertising, a duck can rather easily be transformed into a swan. In this respect every trade mark is potentially a renowned one. ${ }^{10}$

5. 'With reputation', 'dotati di rinomanza', 'jouissant d'une renommée', 'que gozan de renombre', 'notorisch bekannte Marke'.

6. And now 'intramural' too, since the enlargement of the famous trade marks' protection within the same (or similar) sector of registration (see n. 7 below).

7. Precisely, Trade Marks Directive, art 10(2)(c), reads: 'the sign is identical with, or similar to, the trade mark irrespective of whether it is used in relation to goods or services which are identical with, similar to, or not similar to, those for which the trade mark is registered, where the latter has a reputation in the member state and where use of that sign without due cause takes unfair advantage of, or is detrimental to, the distinctive character or the repute of the trade mark' (emphasis added); and EUTM Regulation, art 9(2)(c) likewise reads 'the sign is identical with, or similar to, the EU trade mark irrespective of whether it is used in relation to goods or services which are identical with, similar to or not similar to those for which the EU trade mark is registered, where the latter has a reputation in the Union and where use of that sign without due cause takes unfair advantage of, or is detrimental to, the distinctive character or the repute of the EU trade mark' (emphasis added). The same conditions recurring, a third party's trade mark, identical or similar to a prior renowned trade mark cannot be validly registered, and, if registered, can be declared null and void (Trade Marks Directive, art 5(3)(a); EUTM Regulation, art 8(5)).

8. A regime that has passed substantially intact from the original version.

9. See, eg the C-375/97 General Motors [1999] ECR I-5421, [22 et seq]; C-301/07 Pago International [2009] ECR I-9429 [21-27]; T-291/09 Carrols, EU:T:2012:39 at [68-69].

10. This remark evokes, on a distinct plane, the 'rehabilitating' effect connected to the socalled 'secondary meaning'. Both phenomena are determined by the impact of advertising. 
Secondly, the protection afforded to well-known trade marks is not only expansive materially, that is, vis-à-vis 'not similar' goods, but also geographically. The protection of an internationally well-known mark (within the meaning of article 6-bis of the Paris Convention), even if registered elsewhere, precludes the registration of the same trade mark in any other member country, even in 'not similar' sectors $;{ }^{11}$ and the Court of Justice confirms that, in order to preclude the registration in a member state of a trade mark similar to a prior well-known trade mark, it is sufficient that the trade mark is well known in a substantial part of the EU territory - a part which can correspond to the territory of one member state. ${ }^{12}$ Thus, the extramural extension of the protection can become such also in spatial terms.

These two points should make us all the more attentive to the need to contain the risks to competition deriving from an unbalanced over-protectionist interpretation - in particular, but not only, as concerns the 'leveraging' effect of the exclusive protection.

\section{THE 'EXTRAMURAL' PROTECTION (IE IN 'NOT SIMILAR' SECTORS) OF RENOWNED TRADE MARKS}

Regarding the conditions and scope of the extramural protection, we propose to make an immediate disclosure of our position. Just as in some detective stories revealing the murderer at the onset does not lessen the reader's interest, so we hope that will also be the case here.

Our position rests on a simple postulate: that in the concrete commercial and communication context (thus, taking into account all the circumstances, including 'the degree of similarity between the trade mark and the sign') ${ }^{13}$ the use in a 'not similar' sector of a trade mark identical or similar to a renowned one, can reasonably give rise to a perception (and hence reliance) on the part of consumers that there is a business link - not necessarily 'manufacturing' - between the third party user firm and the owner of the renowned sign. This perception of a 'connection' (article 16(3) of the TRIPs Agreement) can have a contractual nature and basis that also encompasses the relational aspect of the market identity (and associated image) of the firms concerned. Such a connection suggests some form of patronage/involvement/endorsement (or, at least, a mere de facto tolerance) by the owner of the renowned sign, as, for example, in merchandising, sponsorship, joint ventures, co-existence agreements, co-branding, etc. In fact, the consumer is not able to evaluate, from a legal point of view, what kind of juridical relation exists between the trade mark's owner and people who uses his trade mark; it is

11. TRIPS, art 16.3.

12. Pago International, [25, 27, 29], confirmed by C-125/14 Iron \& Smith, EU:C:2015:539. As concerns the territorial extension of renowned trade marks' protection, see ECJ's decision C-235/09 DHL [2011] ECR I-2801. The decision concerns Community trade marks enjoying a 'reputation' only in a part of the EU and used in a member state different from those, constituting a substantial part of the Community, where the trade marks are renowned. The Court denied the extension of injunctive reliefs to EU areas where the use of the trade mark does not interfere with the sign's functions. This means that a community trade mark, renowned even just in a substantial part of the EU territory, can benefit from the enlarged protection, even injunctive, against infringements (as per art 9(1)(c) EUTM Regulation), but only in the member states where the reputation has been acquired, and where the unauthorized use by a third party can prejudice, or risks prejudicing, the renowned trade mark's functions.

13. Trade Marks Directive, Recital (16) which is almost identical to EUTM Regulation art 11. 
necessary, but sufficient, that he merely supposes that 'some kind' of link exists between them. ${ }^{14}$

In this sense, the renowned marks' regime essentially represents a consolidation of a line of interpretation that progressively emerged in doctrine and case law prior to the Directives and Regulations. This line of interpretation extended the notion of confusion by association also to any evocation of those types of 'connection', concluding a path that from the original emphasis on manufacturing origin has gone on to afford importance to the overall mercantile identity - the identity that the contemporary brand industry characteristically 'spends' in the market.

Our position obviously implies the non-acceptance of an opposite line of interpretation that grants the trade mark owner powers of extramural interdiction simply on the grounds of mnemonic evocations of similarities of names, figures or shapes, that is, of mere associative reflexes of an iconic nature between the renowned trade mark and those used by third parties to brand 'not similar' goods. ${ }^{15}$ For example, the stylized eagle that appears on Giorgio Armani garments might instinctively evoke the figurative trade mark on Aston Martin cars; or the truncated cone of a bottle of perfume might remind one of Strega liquor.

This disputed line of interpretation also brings to mind historical examples that are sufficient to undermine its credibility - from the 1924 decision of the Landgericht Elberfeld in the Odol case in which the famous trade mark of a mouthwash had to be protected against an unauthorized use for steel products, ${ }^{16}$ to the assertion that construction

14. In the landmark Italian case Sasso (Supreme Court, 24 March, 1983, n. 2060 (G.A.D.I. 1591/1) - regarding the well-known olive oil trade mark 'Sasso' and a 'Sasso' trade mark for soft drinks - the SC affirmed that 'the scope of protection of trade marks well known or highly renowned goes behind the same or strictly similar products, but within the boundaries of risk of confusion for the consumer, which occurs when he can ascribe to the trade mark's owner the manufacture of other products or erroneously can suppose the existence of legal or economic links between the two firms' (emphasis added).

15. The possibility of the consumer making just a mental association (a sort of déjà vu) being a necessary but also sufficient condition for the application of the extended protection of a trade mark with reputation, is a principle that has been espoused in EU case law since C-408/01 Adidas-Fitnessworld [2003] ECR I-12537. See also CJEU judgments of 18 June 2009, C-487/2007, L'Oréal SA [2009] ECR I-5185 and C-102/07, Adidas III [2008] ECR I-2439. See further L Bently and B Sherman, Intellectual Property Law (Oxford University Press, Oxford 2009) 880. The principle traces its origins back to the Benelux system and the interpretation given thereto by the Courts, for example, in the Claeryn case (Benelux Court of Justice, 1.3.1975, in Ing. Cons. 1975, 73 et seq), in which the name of a famous aperitif coincided with that of a detergent. Or, also, for example, the judgment of the Commercial Court of Bruges of 5 September 1991 (in RIPIA, 1991, 441) in which famous champagne trade marks were used to brand real estate. On this topic see A Braun and $\mathrm{E}$ Cornu, Précis des marques (Larcier, Paris 2009) 287-8. In US literature, see JT McCarthy, On Trademarks and Unfair Competition (2nd edn, Rochester, San Francisco 1984) vol II, 213, according to whom the application of the antidilution rules should be excluded in a case where 'a reasonable buyer is not at all likely to link the two uses of the trade mark in his or her own mind'.

16. The case inspired the well-known article by F Schechter 'The Rational Basis of Trademark Protection' (1927) Harvard Law Review 813. According to Schechter (831-2), the German court "held that the use of the mark "Odol" even on non-competing goods was "gegen die guten Sitten" ("against honest trade usages", i.e. an act of unfair competition) pointing out that, when the public hears or reads the word "Odol" it thinks of the complainant's mouthwash, and that an article designated with the name "Odol" leads the public to assume that it is of good quality. Consequently, concludes the court, the complainant has "the utmost interest in seeing that its mark is not diluted (verwaessert); it would lose in selling power if everyone used it as the designation of her/his goods"'. But, for a recent critical review of the Schechter interpretation of the 
companies would gain an 'unfair advantage' from adopting a famous champagne trade mark to denote an apartment complex, or to the decision which held that a cesspool cleaner's display of its phone number '4711' on its vehicles infringed (by tarnishing) the trade mark of a famous eau de Cologne.

However, even apart from these revealing absurdities, that over-protectionist line should be rejected owing to the following arguments.

\section{ARGUMENTS FOR A PRO-COMPETITIVE ('REDUCTIONIST') APPROACH}

\subsection{Exegetic argument(s)}

Article 16(3) of the TRIPs Agreement, in referring to well-known trade marks to be protected in accordance with article 6-bis of the Paris Convention, states that protection extends to the use of the trade mark for 'not similar goods', provided that such use, in the eye of the consumer establishes 'a connection between those goods and the owner of the registered famous mark, and such use might prejudice that owner's interests' (emphasis added; as regards the reference to prejudice, see below subparagraph 5.2.

Thus, clearly, according to TRIPs, the (context of the) use of the trade mark by a third party must evoke a 'connection' between firms - not just between marks.

A further significant indirect textual comfort comes from a historical milestone of IP law, the Paris Union Convention (PUC). Article 6-ter(1)(c) thereof in substance forbids the use of state signs and other public/institutional emblems, only if such use is

of such a nature as to suggest to the public that a connection exists between the organization concerned and the armorial bearings, flags, emblems, abbreviations, and names, or if such use or registration is probably not of such a nature as to mislead the public as to the existence of a connection between the user and the organization [emphasis added].

Now, let us consider that, mutatis mutandis, (a) official/institutional signs are per se - by definition - 'well known'; and (b) their institutional nature calls, as the ad hoc provision of PUC itself confirms, for a peculiar concern for protection. So - the argument goes - if the protection of such public 'VIP' signs requires the suggestion of a substantial link with the institution-owner, why should private commercial signs be afforded a higher degree of protection, on the basis of a mere iconic coincidence/similarity?!

\subsection{An empirical, and logical, argument}

It seems reasonable to argue that a mere iconic evocation, concerning a quite different type of goods, is per se incapable of fulfilling the first condition set for granting the extramural protection: a damage to the distinctive character or the reputation ('dilution', 'tarnishing') of the renowned sign. It seems indeed difficult to imagine that consumers disappointed by the quality of a ham bearing a trade mark whose wording and graphics are similar to that used by Ferrari cars will think badly of the famous sports car manufacturer.

The same can be said for the dilution of the distinctive character (even apart from the fact that a real risk of dilution by blurring is reasonably unlikely in the absence of a

Odol case, see B Beebe, 'The Suppressed Misappropriation Origins of Trade Mark Antidilution Law: The Landgericht Elberfeld's Odol Opinion and Frank Schechter's "The Rational Basis of Trademark Protection"', in RC Dreyfuss and JC Ginsburg (eds), Intellectual Property at the Edge: The Contested Contours of IP (CUP, Cambridge 2014) 59. 
significant number of instances of 'appropriations' by third parties). One could even claim that the evocation of the well-known sign precisely reiterates hence enhances the sign's distinctive appeal.

This argument seems even more persuasive in the hypothesis of identity/similarity between trade marks that both enjoy high reputation, albeit in different sectors. If the interpretative line refused here were empirically reliable, the firm that had first adopted the famous trade mark should be even more damaged by the subsequent adoption of an identical or similar trade mark by another highly renowned firm operating in a "not similar' sector. A famous new entry would appear to be much more dangerous than a Mr Nobody. The contrary is also true. Now, referring back to the example given above, there is no evidence to suggest that the adoption of a stylized eagle by Armani to mark his clothes clouds the image of Aston Martin, nor that it evokes a business link between the two famous firms.

A similar argument can be submitted in relation to the other condition for extramural protection: an 'unfair' advantage gained by the third party. From what little we know of consumer behaviour, it seems hazardous to suppose that a reasonably informed, observant and circumspect customer ${ }^{17}$ would be influenced in his decision to buy a property in a resort whose name is reminiscent of a famous champagne brand, or can be induced to prefer an aftershave named 'INTESA' having in mind the brand of the famous Italian 'BANCA INTESA'. ${ }^{18}$

Here the empirical argument marries the logical one. If in fact the perception of a semantic coincidence were sufficient to constitute an unfair advantage, the legislative provision on that specific condition would be superfluous. And this precisely because the fame of a trade mark per se conveys, together with the distinctive appeal, a promotional suggestion. Hence, that provision only makes sense if related to the specific postulate emphasized above: that is, a reasonable appearance, suggested by all of the circumstances of the actual case, of some form of 'trade connection' between the third party firm and that of the owner of the trade mark. An appearance that, precisely because it can translate into the previously mentioned 'patronage/involvement' effect, may effectively benefit the goodwill of the user of an identical or similar sign. ${ }^{19}$

17. In the information age, this is the crossbar for protecting customer expectations: see Recital 18 of Directive 2005/29/EC on unfair commercial practices. However, some doubt lingers thereon, in consideration of the typical flood and speed of communications through social networks, smartphone 'apps', and similar. Flood and speed that often hinder considered reflections and hence thoughtful decisions.

18. The Tribunal of Bologna 25 October, 2011 (Giurisprudenza annotata di diritto industriale, 2011, 5955/2) denied protection to the Pirelli trade mark's well-known lengthened 'P' which was recalled by a similar lengthened ' $\mathrm{P}$ ' in the trade mark Pelloni, used for parmesan cheese. According to the judge, 'it appears hardly probable that the average consumer, reasonably wise, at the moment of choosing particular foods (cheese) can be induced to buy them only because attracted from the renown Pirelli trade mark, present in a completely different market sector'.

19. In C-252/07 Intel [2008] ECR I-8823, the Court apparently suggests that a simple iconic link between the signs is not sufficient to acknowledge the dilution of the previously registered and famous one. In fact, in stating (on the basis of its own precedent in the Adidas-Salomon and Adidas-Benelux cases) that an essential condition for the expanded protection of a trade mark with reputation is that the public, on the basis of all of the circumstances of the actual case, can be induced into establishing a 'link', the Court clarified that 'the fact that the conflicting marks are identical, and even more so if they are merely similar, is not sufficient for it to be concluded that there is a link between those marks'. Confirmation of this interpretation of the decision comes from the passage (n. 77) in which the Court rules out that the existence of 
Finally, again with regard to the condition in question, one can rightly ask whether the unfair 'advantage' must in the ultimate analysis correspond to a 'prejudice' suffered by the owner, typically consisting of a reduction of her/his commercial chances of expansion in a different sector. This interpretation is coherent with the text of article 16(3) of the TRIPs Agreement, pursuant to which the enforcement of the unauthorized use for not similar products requires the evidence of a 'prejudice' of the owner's interests - thus, not also of a separate unfair 'advantage'. However, the literal argument aside, what can such 'advantage' consist of if not a subtraction of chances of profit (in the 'not similar' sector) from the famous trade mark's holder (the same kind of 'consent price' requested in the case of the unauthorized use of the name/image of a famous actor or sportsman)?

just any link is sufficient to warrant extension of the protection: it must be a link capable of determining an actual or potential modification of the consumer's economic behaviour. Undoubtedly such a specific impact on the choices made by the public cannot reasonably be supposed on the basis of an iconic coincidence not backed up by the consumer's conviction that the use of the later mark is in some way endorsed by the owner of the earlier, famous mark.

This principle was restated by the CJEU decision C-383/12 Environmental Manufacturing ('WOLF'), EU:C:2013:741 at [34, 36 and 37]: 'According to the Court's case-law, proof that the use of the later mark is, or would be, detrimental to the distinctive character of the earlier mark requires evidence of a change in the economic behaviour of the average consumer of the goods or services for which the earlier mark was registered, consequent on the use of the later mark, or a serious likelihood that such a change will occur in the future. ... It follows that, without adducing evidence that that condition is met, the detriment or the risk of detriment to the distinctive character of the earlier mark provided for in Article 8(5) of Regulation No 207/ 2009 cannot be established. The concept of "change in the economic behaviour of the average consumer" lays down an objective condition. That change cannot be deduced solely from subjective elements such as consumers' perceptions. The mere fact that consumers note the presence of a new sign similar to an earlier sign is not sufficient of itself to establish the existence of a detriment or a risk of detriment to the distinctive character of the earlier mark within the meaning of Article 8(5) of Regulation No 207/2009, in as much as that similarity does not cause any confusion in their minds' (emphasis added). The same applies to the risk of dilution: see inter alia the Moseley case, where the US Supreme Court (418 (2003), 259 F.3d 464) stated that 'we do agree, however, with that court's conclusion that, at least where the marks at issue are not identical, the mere fact that consumers mentally associate the junior user's mark with a famous mark is not sufficient to establish actionable dilution' (emphasis added). See further the New York Supreme Court (in Cue Publishing Co. v ColgatePalmolive Co., 45 Misc. 2d 161), that, after recalling the words of Judge Learned Hand in Yale Electric Corporation v Robertson (C.C.A.) 26 F. 2d 972 (' $\ldots$ it has come to be recognized that, unless the borrower's use is so foreign to the owner's as to insure against any identification of the two, it is unlawful') stated that 'it would appear therefore ... that to give effect to the dilution doctrine some measure of confusion must be present and in those cases where it was found to exist the rights of the senior user were upheld' (emphasis added).

Then, with reference to the use of trade marks on the Internet, the US District Court of California, in Nissan Motor Co. Ltd v Nissan Computer Corporation, 20 September 2007 (available at: http://www.nissan.com/Lawsuit/The_Story.php), observed that 'ownership of a famous mark does not result in automatic entitlement to ownership of the mark as a domain name; there is no authority for such a per se rule', and accordingly ruled out that registration of the domain name 'nissan.com' by the Nissan Computer Corporation constituted dilution of the more famous Nissan automobile trade mark. The Court pointed out that in light of the facts of the case 'it takes only "one hot second" for an internet user looking for Nissan Motor to realize that nissan.com is not the site of a very large car company that has spent millions of dollars on high quality advertising'. In other words, there was no chance that a consumer would ever suppose that the owners of these two trade marks were in any way associated. 


\subsection{Arguments of a systemic character: preliminary rejection of the assertion of a legal 'investment function' of trade marks}

The 'reductionst', 'brand-sceptic' (to borrow from William Cornish) ${ }^{20}$ (hence) procompetitive line that we support might run in contradiction to some well-known dicta of the Court of Justice of the European Union (CJEU, formerly ECJ) ${ }^{21}$ asserting a legal 'function of investment' of trade marks - an assertion that often tautologically overlaps with that of an 'advertising function'. ${ }^{22}$ This function is implicitly but clearly assumed as separate and independent from the distinctive (origin) function of trade marks. Authoritative as the CJEU cases are, this assertion lacks, in our view, a serious legal foundation.

Before proceeding in arguing our position, let us clarify that the very notion of 'legal function' properly refers to a normative datum that defines, or concurs to define, either the conditions or the scope (or both) of a given legal regime, in this case that of trade mark law. In other words, a 'legal function' is definitely not the jurispolitical motivation, that is, the (economic/social/political) rationale underlying a certain regime. ${ }^{23}$ Nor does it represent the economic/social/political effect stemming from that regime. It is, to reiterate, a normative tenet 'built in' to the discipline, one that permanently 'shapes' it.

Now, this is also the case with trade mark law - either as concerns the traditional protection, which is juridically conditioned by the mark's distinctive character and the occurrence of confusing activities, or even as concerns the 'enlarged' (extramural) protection accorded to 'famous' marks. Indeed, no matter what investment might have been made, in the current normative framework the protection is not available if the trade mark has not (first of all) objectively attained a 'distinctive character', or it has not objectively acquired adequate 'reputation', or the unauthorized use of a similar trade mark by third parties has not caused either an actual prejudice to the famous mark's reputation or distinctiveness, or an actual unfair advantage to the third user. ${ }^{24}$

20. W Cornish, Intellectual Property: Omnipresent, Distracting, Irrelevant? (OUP, Oxford 2004). 21. See in particular, C-323/09 Interflora v Interflora British Unit [2011] E.C.R. I-08625 and other court law cited therein. According to the Court, the use of the trade mark as described above adversely affects the trade mark's investment function 'if it substantially interferes with the proprietor's use of its trade mark to acquire or preserve a reputation capable of attracting consumers and retaining their loyalty'. On trade marks' alleged 'other' functions see also the CJEU's decision in Case C-65/12 Leidseplein Beheer BV v Red Bull, EU:C:2014:49 and C-661/11 Martin Y Paz, EU:2013:577.

22. See Michel Vivant 'Revisiting Trade Marks' (2013) 3 QMJIP 307. We say 'tautologically' since, as a matter of fact, the two asserted 'functions' are Siamese twins: the 'investment' in enhancing a trade mark's reputation is essentially an investment in advertising.

23. See Enrico Bonadio, 'Patents as Tools to Encourage the Production of Healthier Food', in Alberto Alemanno and Enrico Bonadio (eds), The New Intellectual Property: Beyond Plain Packaging (Edward Elgar Publishing, Cheltenham 2016) 305 (taking, on the one hand, the proposals to patent foodstuff as encouraging investments in the production of healthier food) and Andrew D Mitchell, 'Tobacco Packaging Measures Affecting Intellectual Property Protection Under International Investment Law: The Claim Against Uruguay and Australia', in Alberto Alemanno and Enrico Bonadio (eds), The New Intellectual Property: Beyond Plain Packaging (Edward Elgar Publishing, Cheltenham 2016) (arguing, on the other hand, the claims brought by leading tobacco industries against regulations affecting the branding, labelling and packaging of tobacco, allegedly 'punitive' of investments embodied in intellectual property, and the ensuing WTO arbitration procedures).

24. See Vincenzo Di Cataldo, 'The Development of Trade Marks into Common Names of Products: A Strong Push Towards a Purely Objective View of Language Evolution', in 
From a systemic point of view, our critical position about the alleged 'investment function' is first of all based on a fundamental tenet of the intellectual property system: exclusive protection is only granted to objective achievements (dixit Josef Drexl, in a conversation) of specific general interests. In essence, this is the tradeoff, so poignantly sculpted by the US Constitution (article 1.8.8), between a private 'monopoly' and the creation of a socially useful effect. Take patents and copyright: only new intellectual works, and new technological solutions, qualifying as contributions to the advancement of 'science and the useful arts' justify the exclusive protection against (economically significant) free riding. And of course, for the trade-off to be effective, the contribution must be embodied in an objective result of intellectual effort possessing the requisites requested by the law in order to fulfil the social function. 'Investments' per se do not enter the legal landscape. By means of a patent the legal system protects new and non-obvious inventions, no matter what investment, huge or otherwise, may have been spent on the aborted research, or even on an invention not first-filed. Likewise, copyright rewards an expressive result, whose auctor (from latin augere $=$ to increase) enriches the cultural heritage: again, no protection is afforded, whatever the investment may have been, ${ }^{25}$ to the efforts and attempts that never led to a publishable work. Undisputedly, neither patents nor copyrights are there to protect the author's ability and investments to promote their commercial reputation.

So it is also the case, even allowing for all due differences, with trade marks. What is their socially useful function (indispensable function, in a market characterized by a potentially indefinite plurality of industrial and commercial offers) if not to ensure 'distinguishing information', that is, market transparency about the origin of the goods? Can we reasonably define as of general utility - and as such worthy of a monopolistic exception potentially unlimited in time - the diffusion of advertising suggestions that exalt the brand image?! It is unquestionable that such advertising and marketing efforts, aimed at enhancing the fame of the trade mark, do require strong investments. But as investments per se do not constitute a legally relevant basis for patent and/or copyright protection, we see no reason for claiming that the opposite should be true for trade marks.

Furthermore, on the less decisive but not insignificant exegetic perspective, no mention of an 'investment' (or 'advertising', etc.) function can be found in either the Directive or the Regulation, even in the 2015 versions. As a matter of fact, in defining the scope of protection of the Community trade mark (or EU trade mark under the amended 2015 versions), these legislations make sole express reference to the defence against confusion, including by 'association'. ${ }^{26}$ The sole express reference, thus, is to the distinctive function as 'the' legal function of trade mark protection as indicated in

Gustavo Ghidini, Hanns Ullrich and Peter Drahos (eds), Kritika: Essays on Intellectual Property, Vol II (Edward Elgar Publishing, Cheltenham 2017) 119 (analogizing that if a once distinctive sign objectively becomes a generic term in the trade parlance, the owner would lose the entitlement through 'vulgarization', no matter how much money she had poured into defending and promoting the sign).

25. As concerns copyright, Ulrich Loewenheim recently wrote that 'Das Urheberrecht schützt die geistige Leistung und nicht die Investition [Copyright protects the intellectual result and not the investment]' in Ulrich Loewenheim (2016) Zeitschrift für Geistiges Eigentum 568, 571 (reviewing Marcel Bisges, Kleine Münze im Urheberrecht: Analyse des 'ökonomische Aspects des Werkbegriffs (Nomos, Baden-Baden 2014)).

26. EUTM Regulation, Recital (11). 
Recital 16 of the Trade Marks Directive. ${ }^{27}$ In truth, the overall wording has some margin of ambiguity, as these Recitals hint at the distinction as the 'central/fundamental' function - not as 'the' function across the board. But it seems all too reasonable to assume that if the European legislator had really meant to engage in expanding the legally protected functions of trade marks, one can reasonably suppose that they would have mentioned it. Anyway, it is certain that there is no legislative recognition of such 'function'. Above all, it is certain that, as emphasized, 'investment' does not define either a condition or the scope of the legal protection of trade marks.

Thus the evocation of the 'investment function' as a separate legal function in addition to the distinctive function, appears to be a systemic nonsense, since - in the words of Felix Cohen about the false 'if value, then right' doctrine - it 'purports to base legal protection upon economic value, when, as a matter of fact, the economic value of a sale device depends upon the extent to which it will be legally protected' 28

In sum, the assertion of the CJEU (mis)identifies the de facto enhancement of an economic projection (effect) with its legal expression - and foundation. In other words, this (mis)identification blurs the distinction between economic assessment and legal conditions and limitations of trade mark protection. ${ }^{29}$

Now, this quid pro quo is no innocuous lapse: it carries a systemically improper corollary of substantive anti-competitive momentum. Affirming that the 'investment function' is a legal function - that is, that the factor 'investment' as such impacts on the legal protection - corresponds, from a systemic perspective, to surreptitiously bypassing the cardinal principle that expresses the primacy of freedom of competition: the principle of the legislatively circumscribed, 'closed' number (numerus clausus) of exclusive IP rights.

In turn, this bypassing can open a Pandora's Box of substantive consequences of a strongly 'protectionist' (ie anti-competitive) character. First and foremost, it provides the justification for affirming that firms' goodwill must be protected as such, in contradiction to the golden rule that it can only be defended against tortious activities, such as counterfeiting and acts of unfair competition - essentially the passing off and slandering of goods. In logical sequence, this can straightforwardly lead to an expansive

27. See Trade Marks Directive, Recital (16).

28. Felix Cohen, 'Transcendental Nonsense and the Functional Approach', 35 Colum. L. Rev. 809, 815 (1935). See also Gustavo Ghidini, Hans Ullrich and Peter Drahos, 'Editorial', in Kritika: Essays on Intellectual Property, Vol II (n 24) xiii.

29. The support of investments is merely a de facto economic consequence of the extramural reach of the protection of renowned marks; just as protection of the distinctive function itself de facto enhances the investments used to elaborate and support a sign and to extoll its distinguishing capacity. In analogous terms, the legal recognition of the 'rehabilitating' effect of the acquisition of a distinctive character (secondary meaning) by an originally 'generic', hence, null trade mark, de facto protects the investments in advertising that created that 'new' meaning. But this is a de facto economic projection of the legal protection, not the object nor a condition thereof, nor does it define the scope of the legal protection. The double-check: if, notwithstanding intense investments, a descriptive sign did not acquire a sufficient distinctive character or 'secondary meaning', the consequent 'rehabilitating' effect would not take place. Thus, in the same terms, investments in advertising and marketing poured into supporting a trade mark whose object is a shape that is exclusively or predominantly functional cannot be registered or validated (see EUTM Regulation, art 7(1)(e)(i) and (ii); Trade Marks Directive, art 4(e)(i) and (ii)). 
(protectionist, as said) approach to the protection of 'famous' trade marks: even in the sense of granting them protection just on the basis of a mere iconic similarity or coincidence, even in default of the appearance of any reasonable appearance of a business 'connection', as in the TRIPs agreement (article 16.3 of TRIPs), between the rights holder and third parties acting in distant industrial or commercial sectors. ${ }^{30}$ This is a result that serves primarily the interests of dominant business circles, ${ }^{31}$ and much less the cause of freedom of enterprise - as the freedom to use signs (including words, colours, shapes, and so forth) to identify one's products is indeed (also) part of the general freedom of enterprise. ${ }^{32}$

The evocation of the 'investment function' appears to be a refreshed version of the so-called 'misappropriation doctrine' that the United States spelled out in Int'l News Service v Associated Press, while in Europe it received some support, starting in the early twentieth century. ${ }^{33}$ This doctrine evoked the right to "the fruits of labor achieved by toils and expenses', with the aim of protecting goodwill as a 'quasiproperty', stretching beyond the boundaries of confusion (referred to as palmingoff/passing-off). ${ }^{34}$ This is, however, a scientifically discredited thesis, systemically inconsistent with the general framework of IP law, as well as being deeply anticompetitive.

\section{Art 16.3 TRIPs.}

31. Significantly, the assertion of the 'investment function' also works as an instrument to support the leading industrial circles' battle against 'lookalikes', ie even non-confusing imitations of branded goods (see in particular Davidoff and Adidas II). A line seemingly confirmed by the 2015 'package' (art 10(2)(c) Trade Marks Directive and art 9(2)(c) EUTM Regulation) that grants an extended protection to famous trade marks, not only outside but also within the sector of registration and similar ones. 'Seemingly', to repeat: in truth (the normative truth), even vis-à-vis identical or similar products, the protection of the mark's 'notoriety' only can take place when in the specific case, and in the light of all the circumstances thereof, the use of an identical or similar sign objectively causes (effectively, not potentially: see aforesaid norms) either 'an 'unfair advantage' or a 'detriment' to the distinctive character or the repute of the renowned mark. Now, this can only happen, as exposed in $\S 4$, if and when the public is led to reasonably assume the existence of an objective business 'connection' (art 16(3) TRIPs) between the third user and the owner's firm (NB: not just between the signs as such, on the basis of a merely iconic resemblance) - thus, ultimately, in the presence of a substantively confusing 'association'. Obviously, the closer the affinity, up to the borderline case of full identity, between the branded products, the higher is the likelihood that either the 'unfair advantage' or the 'detriment' occurs.

32. See Mark A Lemley and Eugene Volokh, 'Freedom of Speech and Injunctions in Intellectual Property Cases' (1998) 48 Duke L.J. 147 (1998).

33. Int'l News Service v Associated Press, 248 U.S. 215 (1918). See, however, the dissenting opinions of Justice Holmes and Justice Brandeis, the former affirming that 'property, a creation of law, does not arise from value', and the second that 'the fact that a product of the mind has cost its producer money and labor, and has a value for which others are willing to pay, is not sufficient to ensure to it this legal attribute of property'. See also the criticism expressed by Felix Cohen (n 28) about the false 'if value is right' doctrine.

34. This kind of argument was affirmed in Germany in the early twentieth century by RG 1926, 30 October in GRUR 1927, 133; ibid 1910, April 7, in RGZ 73, 296; and Hermann Isay, Das Rechtsgut des Wettbewerbsrecht, Berlin, 1933, 59 ff. See the critical reconstruction and assessment of this doctrine, starting from the German Odol case (1924), by Barton Beebe (n 16). 
In sum, the theory that ... investissement vaut titre ('investment builds entitlement') has no 'right of citizenship' within IP law, also in respect to trade mark law. ${ }^{35,} 36$ Vice versa, the ship should be firmly steered towards the sacrosanct principle, of British origin: 'Neither the market nor the customer are the plaintiff's to own. There is no tort of making use of another's goodwill as such'. ${ }^{37}$

\subsection{A systemically inconsistent corollary of the position opposed}

Finally, the adherence to the criticized interpretative line would paradoxically have the consequence of protecting the reputation of trade marks, thus of products, more intensely than that of human persons. This is an absurd discrimination, and one that blatantly clashes with the constitutional principle of equality under the law. Famous sports stars can prohibit the use of their name, evocative of their reputation, if such a mention can lead the public to believe that they are sponsoring this or that product or initiative. No wrongdoing, no power of interdiction would emerge if the context in which the name is mentioned may simply lead to thinking of a coincidence with somebody else's name. Coincidence and namesake do not constitute false misrepresentation precisely because in the eyes of the public the famous persons are not seen as being 'involved'. So, for what reason should trade marks for industrial products be afforded more intense protection than that granted to humans?!

\subsection{The negative impact on competition of the position opposed}

From an essentially private perspective, that is, one mainly centred on the individual conflict of interests between rights holders and third party (entrepreneurial) users, the behaviour of those who adopt, even in a distant sector, a sign identical or similar to one made famous by others (even if just through spending on advertising and successful sponsorship) may well appear less deserving of protection than the position, though rent-seeking, of the trade mark holder, who, after all, has worked and spent to build up the fame of its sign.

35. Paraphrase of the classical principle, reaffirmed by the Napoleonic Code, concerning the transfer of the possession of movable goods from a non-owner to third parties: if the latter are in good faith 'possession entitles', ie they acquire the property 'en fait de meubles, la possession vaut titre'. There is one single normative (seeming) exception to the assertion that investment is not relevant for entitlement: the sui generis right (famously defined as 'a legal monstrosity' by Jerome H Reichman) on the information stored in databases (Council Directive 96/9/EC, art 7-11 1996 O.J. L. 77/20): see J Drexl, 'Intellectual Property Rights as Constituent Elements of a Competition-based Market Economy', Intellectual Property and Market Power, ATRIP Papers 2006-2007, 167 ss. Seeming exception, indeed: such a right is not an IPR right in the proper sense as it cannot be enforced in absolute terms - here meaning even against partial infringements irrespectively of the measure thereof - but only depending on the assessment of a qualitative or quantitative degree ('substantial') of the investment as well as of the unauthorized data appropriation (Council Directive 96/9/EC, art 7.1). Thus, in fact, the sui generis right embodies the (one and only - beyond of course IPRs' infringements) normative recognition of 'parasitism', ie the (one and only) normatively affirmed exception - not to the IPRs regime but to the principle overarching unfair competition law whereby there is 'no misappropriation without misrepresentation'.

36. And beware the risk that this fake theory moves further on from the sector of trade marks, poisoning the whole field of IP law: Gustavo Ghidini, Peter Drahos and Hanns Ullrich, 'Editorial', in Kritika: Essays on Intellectual Property, Vol II (n 24) xiii.

37. Hodgkinson \& Corby $v$ Ward [1997] F.S.A. 178. 
But the horizon is broadened so as to take into account the effects on the market of an extramural protection of almost unlimited scope, as highlighted and criticized. Here, indeed, a number of significant risks for competition emerge.

Firstly, the approach highlighted greatly widens the owner's capacity to preempt third parties' competition in 'distant' markets, restricting the freedom to adopt a sign that in such markets is not confusing (and also not suggestive of a business link with the famous mark's firm). Indeed, the right to choose a distinctive sign (obviously, to repeat, in the absence of any type of misrepresentation) impacts on the degree of freedom of access to a given market. ${ }^{38}$

In antitrust terms, and in the presence of a dominant position (at times enjoyed or reinforced due to the very fame of the trade mark), this translates into a boost of the potential leverage of that position to new markets.

This is an aspect of the exploitation of well-known trade marks of high interest to groups, conglomerates in particular, with a multi-business financial investment capacity. This is consistent with the typical international projection of such groups and their interests (historically well served by the rule of article 6-bis PUC) that trade marks with a reputation in the EU will be protected in every member state where they have acquired 'reputation', even though they are registered in just one of them. Secondly, the line of interpretation rejected here also gives rise to analogous concerns regarding arbitrary restrictions on the freedom of business communication as regards non-distinctive uses of trade marks. It would risk authorizing the owner to prevent the use of the sign by others for the purposes of, for example, parody, ${ }^{39}$ comparative advertising,${ }^{40}$ or display on toy car models to make a proper replica, or to signal non-original spare parts' functional destination. ${ }^{41,42}$

38. On the freedom of language as economic freedom, see M Lemley and E Volokh, 'Freedom of Speech and Injunctions in Intellectual Property Cases' (n 32). M Bjoerkenfeld, 'The Genie is Out of the Bottle: The ECJ's Decision in L'Oréal v Bellure' (2010) JIPLP 106, highlights the risk that a trade mark holder's private interest-oriented interpretation of the third user's 'unfair' advantage might 'restrict the scope for using a familiar trade mark or its imagery as a general tool of communication'.

39. Tribunal of Milan, decision as of 4 March 1999, Giur. Ann. Dir. Ind., 1999, 3987/1, condemned the sale of trade mark shirts bearing Agip's famous six-legged dog trade mark and in which the word 'Acid' rather than 'Agip' was depicted coming out of the dog's mouth. In the opposite direction, the Tribunal of Milan, 31 December 2009, held that an ironic imitation of the yellow Deutsche Grammophon label on an indie record was not translated into an unfair commercial advantage for the competitor as it was an 'ironic citation ... with an evident intent to parody'. In US case law see Barbie, Mattel, Inc. v MCA Records, Inc., 296 F. 3d 894 (9th Cir. 2002), ruling out that a song called 'Barbie Girl', parodying the famous doll, constituted dilution of the Barbie trade mark. See also Louis Vuitton Malletier S.A. v Haute Diggity Dog, LLC, 507 F. 3d, 252, 267 (4th Circ. 2007), which held that the use of some famous trade marks with an intent to parody in order to distinguish animal products did not amount to dilution of the capacity to distinguish.

40. C-487/07 L'Oréal [2009] ECR I-5185 with a note by V Di Cataldo, 'The Trade Mark with a Reputation in EU Law - Some Remarks on the Negative Condition "Without Due Cause" (2011) IIC 66.

41. C-48/05 Adam Opel [2007] ECR I-1017 at [18], implicitly denying the descriptive nature of such use, maintained that the use of a sign identical to the famous Opel trade mark on toy models of Opel cars constituted 'use in the course of trade' within the meaning of article 10(2) of the Trade Marks Directive, and was hence infringement. On this point see A Kur, 'Confusion Over Use? Die Benutzung "als Mark" im Lichte der EuGH Rechtsprechung' (2008) GRUR Int. 1 et seq.

42. Provided of course that there is no likelihood of confusion and hence the manufacturers of toy models and spare parts clearly use their own general trade marks (corresponding to their own firm). 
In short, extending the exclusive extramural protection of well-known trade marks beyond the boundaries of a reasonable appearance of business relations between the firms involved, would cause anti-competitive effects of indeterminate breadth. Any time that iconic identity or similarity would bring to mind the well-known trade mark would entitle the owner to impede the use of names, shapes, colours, etc. even in distant sectors in which the owner has not evidenced any intention of entering.

Thus, in conclusion, how can one fail to agree with Marco Ricolfi, who when, commenting on the 'long expansionist march of the protection of renowned trade marks' stresses that 'the balance of interests ... achieved tends to favour the incumbents long since operating in the market instead of stimulating the birth and the growth of those newcomers whose dynamic energies old Europe so badly needs'. ${ }^{43}$

In any case - whatever concept of 'link' might be adopted - the need to reduce the risk of penalizing the freedom of business communication, hence of competition across-the-board - should lead to a rigorous application of the statutory conditions laid down for extramural protection of trade marks with reputation: unfair advantage of the third user, or prejudice for the owner. This in fact is proscribed by the CJEU in Wolf. Such rigour should directly shape the rules governing the burden of proof of said conditions. Hence, the burden to prove the loss or unfair advantage in concrete and objective economic terms should fall on the owner. This could mitigate the potential leverage of market power potentially connected with the excluding power of the wellknown trade mark in unrelated, 'distant' markets.

\section{AGAINST THE EXTENSION OF THE EXTRAMURAL PROTECTION TO NON-REGISTERED TRADE MARKS}

The extramural protection for registered well-known trade marks should not be extended to unregistered ('de facto') trade marks. Such an extension would contrast with a pro-competitive construction of the relationship between registered and de facto trade marks, which requires a strict interpretation of the extended protection that the reform has accorded to registered trade marks. Even by legal logic that thesis seems inconsistent. Moreover, one can only vainly seek support for this in Directive $89 / 104 / \mathrm{EEC}$, whereby the owner of a prior de facto sign can block registration of a subsequent trade mark. For, it is easy to counter that the rule whereby a prior $d e$ facto trade mark can invalidate a subsequent registered trade mark simply reflects the fact that the subsequent sign was not novel. Now, what has this to do with defining the scope of protection of de facto trade marks?!

Nor might that extension be reasonably supported by referring to the invalidating effects of 'well-known marks' within the meaning of article 6-bis of the Paris Convention, including products that are 'not similar'. These marks must in fact belong to 'a person entitled to the benefits of this Convention': hence to a registered owner. Article 6-bis relates to the case (which does not concern de facto marks) of a trade mark registered in country $\mathrm{X}$ and well-known also in country $\mathrm{Y}$. It establishes that such renown, also in the absence of registration covering country $\mathrm{Y}$, can preclude registration in that country of a trade mark likely to cause confusion.

43. Personal translation from M Ricolfi, "Le nozioni di "somiglianza" dei marchi e di "nesso" nella disciplina dei marchi notori', in Studi in memoria di Paola A.E. Frassi (Giuffrè, Milan 2010) 557 , at 559. 
In conclusion, rules that restrict freedom of competition by precluding third parties from adopting commercial signs that were previously available must be strictly interpreted. Extension by analogy is not possible for that aspect (as opposed to merely ancillary aspects - like, for example, the recourse to injunctive reliefs - which have nothing to do with the objective scope of protection).

Needless to say, this systemic tenet bars any attempt to achieve such an extension by the instrumental evocation of 'parasitism' in the usual function to prohibit non-confusing imitations of formal elements of products' presentation ('lookalikes'). Indeed, even accepting (though we do not) that the protection of renowned marks can be extended beyond the boundary of the concept of confusion, such extension should be construed as a legislative exception, and hence subject to strict interpretation.

\section{MORE INTENSE PROTECTION EVEN IN THE SAME OR SIMILAR SECTORS? DISSENTING OPINION}

The experience of commerce confirms that the selling power of a well-known trade mark is best and more frequently exploited in the sectors for which the trade mark has been registered and those that are similar - the sectors where the sign's fame is directly rooted in the firm's actual expertise, tradition and consumers' fidelity. In other words, and as mentioned before, the selling power manifests and exercises itself above all intramurally. And here it blends with the concept of distinctive character, even reinforcing it - in the sense that the more well-known a trade mark is the more immune it is from confusing associations with other similar signs because its notoriety imprints it in the minds of consumers in a sharper and surer way. The more famous it is, the more 'exactly' known - and recognizable - it is. Fans of sports footwear know full well that two or four lateral stripes 'is not Adidas'. (Every academic year our students, specifically questioned, invariably confirm this.)

This fact must lead to a criticism of the interpretative line affirmed by some decisions of the CJEU, for example in Davidoff and Adidas $I I,{ }^{44}$ to the effect that well-known trade marks should receive more intense protection, even intramurally. This can be accepted (just) in terms of a reasonable presumption ('strong' but not absolute) ${ }^{45}$ of a confusing effect, only in the case of 'double identity' (straight, 'identical' reproduction of the registered trade mark for branding goods of identical kind: above, note 7). In contrast, if the third party's sign, even used in the same sector, were not identical but just similar, the fame achieved by the original trade mark would 'immunize' it from

44. See C-414/99 and C-416/99 Davidoff [2001] ECR I-8691 and C-408/01 Adidas II [2004] ECR I-12537. Only seemingly, as argued above - (n 31) and accompanying text - this line is supported by arts 9(1)(c) and 8(5) of the EUTM Regulation, and arts 10(2)(c) and 5(3)(a) of the Trade Marks Directive.

45. According to the CJEU (see eg C0323/09 Interflora [2011] ECR I-8625 at [33 et seq]) also in the case of 'double identity' the exercise of the exclusive right conferred by the trade mark must be reserved to cases in which a third party's use of the sign adversely affects, or is liable to adversely affect, the functions of the trade mark, in particular its essential function of guaranteeing to consumers the origin of the goods (see also Case C-206/01, Arsenal Football Club [2002] ECR I-10273, [51]). According to art 16.1 TRIPs, 'in case of the use of an identical sign for identical goods or services, a likelihood of confusion shall be presumed'; see also Recital 11 of EUTM Regulation: 'The protection afforded by an EU trade mark, the function of which is in particular to guarantee the trade mark as an indication of origin, should be absolute in the case of identity between the mark and the sign and the goods or services.' 
confusion. Hence infringement should normally be ruled out for the very reason that the more known the trade mark is, the more 'exactly' known it is, in detail. Thus, outside the case of double identity, there would be no legitimate justification to presume confusion, hence restraining competitors from using motifs and elements of the (not unlimited) iconographic heritage (like that of stripes, as in the Adidas cases).

Thus, the opposite stance adopted ten years ago by the CJEU in Picasso/Picaro (January 12, 2006, C-361/04, confirming EU Tribunal June 22, 2004, T-185/02) is still worth support. ${ }^{46}$ All the more so since the criticized approach displays, under the umbrella of an alleged logic coherence, a strongly disproportionate anti-competitive charge, instrumental, again, to the 'ongoing battle against lookalikes' conducted by leading industrial circles. This is an even more intense charge where that approach seeks to retroactively protect a trade mark that has since become well known against variations that are unlikely to confuse anybody made by competitors before the trade mark became famous.

In conclusion, the thesis here supported whereby the extramural protection postulates the occurrence of a reasonable appearance of a business connection between the third user's firm and that of the famous trade mark's holder, should a fortiori apply to the case of 'intramural' use. Also in this case, 'notoriety' is not protected per se, but only in the limit of a misleading perception induced in consumers' minds.

46. In Italy, the same stance was adopted by the Tribunal of Bologna in 2012: decision as of June 4, 2012, in Giur. ann dir ind., 2013, n. 5980/3. 